\title{
A Rare Cause of Peripheral Facial Paralysis in Childhood in Our Country: Lyme Disease
}

\section{Ülkemizde Çocukluk Çağında Periferik Fasiyal Paralizinin Nadir Bir Nedeni: Lyme Hastalığı}

\author{
Emine Özdemir, Dolunay Gürses \\ Pamukkale University Faculty of Medicine, Department of Pediatrics, Denizli, Turkey
}

\begin{abstract}
Lyme disease is a zoonosis caused by Spirochetes called Borrelia burgdorferi, involving several areas, such as the skin, heart and central nervous system. In this case report, we present a 10-year-old male who had complaints of fever, extensive oral aphthae, perioral dried sores, rash, blurred vision and peripheral facial paralysis, and was diagnosed with Lyme disease. In this report, we want to emphasize that Lyme disease should be kept in mind for differential diagnosis in patients with fever and peripheral facial paralysis. Keywords: Facial paralysis, Lyme disease, Borrelia burgdorferi
\end{abstract}

\section{öz}

Lyme hastalığı, Borrelia burgdorferi isimli Spiroket in neden olduğu, deri, eklemler, kalp ve santral sinir sistemi gibi çok sayıda sistemi tutan bir zoonozdur. Bu olgu sunumunda; ateş, yaygin oral aft, peroral kurutlu yaralar, döküntü ve görmede bulanıklık yakınmaları ile getirilen ve periferik fasiyal paralizi saptanarak, Lyme hastalığı tanısı koyulan 10 yaşında bir erkek olgu sunuldu. Ateş ve periferik fasiyal paralizi ile başvuran hastalarda ayırııı tanıda Lyme hastalığının da akııda tutulması gerektiği vurgulanmak istendi.

Anahtar Kelimeler: Fasiyal paralizi, Lyme hastalığı, Borrelia burgdorferi

\section{Introduction}

Lyme disease is a zoonosis caused by Spirochetes of the Borrelia species and transmitted to humans by lxodes ticks (1). While the incidence is reported to be about 30.000 per year in America, it is rare in our country and its incidence is not precisely known. The first Lyme cases in our country began to be reported after 1990, and vector tick species were identified (2-4). A high incidence is reported in the 5-10 age group and it doubles up in adolescents and adults. The incidence rate due to the transmission via ticks increases during the spring season.

Lyme disease is a condition that can be seen in various parts of the body including the skin, heart and the central nervous system (CNS). Clinical manifestations are grouped in two stages as early and late. The most important finding of the early stage is erythema migrans. The late stage findings are observed months later in the patients that have not been treated properly. While the most common finding in this stage is arthritis, CNS involvement is also observed (2). Although Lyme disease is a rare cause of facial paralysis in children, it can also emerge as the only finding of the disease $(2,5)$. In this report, we present a 10-year-old male case with complaints of extensive mouth sores, oral ulcerations, skin rashes and blurry vision, who was admitted to our department and diagnosed with isolated facial paralysis and Lyme disease. 


\section{Case Report}

A 10-year-old male case was referred to our hospital presenting with fever, extensive sores in and around the mouth, rashes and blurry vision. A 14-day history of the patient revealed that he had received a two-day irregular treatment with amoxicillin-clavulanate for fever, fatique and sore throat. Consent form was filled out by the family of the patient. The patient had been hospitalized because they were unable to bring down his temperature; and he had developed oral ulcerations, vesicular skin rashes around the mouth and face. So, he was referred to our department being unable to feed orally, and blurry vision although he was still under treatment. There was no history of staying in the countryside and being in contact with animals except for going on a picnic 15 days prior to the complaints. The patient was a thalassemia carrier and no characteristics were detected in the pedigree.

Physical examination revealed that his weight and height were $41 \mathrm{~kg}(75-90 \mathrm{p})$ and $147 \mathrm{~cm}(90-97 \mathrm{p})$ respectively. Armpit body temperature was $38.4{ }^{\circ} \mathrm{C}$, respiratory rate and heart rate were 18/min and 102/min respectively, and his blood pressure was $106 / 74 \mathrm{mmHg}$. There were dried lesions around the mouth and on the lips, extensive major oral ulcerations and several gutta-sized central squamous papular rashes (Figure 1). Respiratory and cardiovascular system examinations were normal and the liver could be palpated $1 \mathrm{~cm}$ below the level. Neurological examinations showed disappearance of nasolabial sulcus on the left side, ptosis on the left corner of the mouth and right shift of the corner of the mouth, and that the patient was unable to completely close his left eye. Fundoscopic examination and the examination of other cranial nerves were normal. Strength of the leg and arm muscles were also normal, and deep tendon reflexes were normoactive.

Laboratory analyses showed that his hemoglobin level was $11.8 \mathrm{~g} / \mathrm{dL}$, hematocrit level was 36\%, and the leukocyte

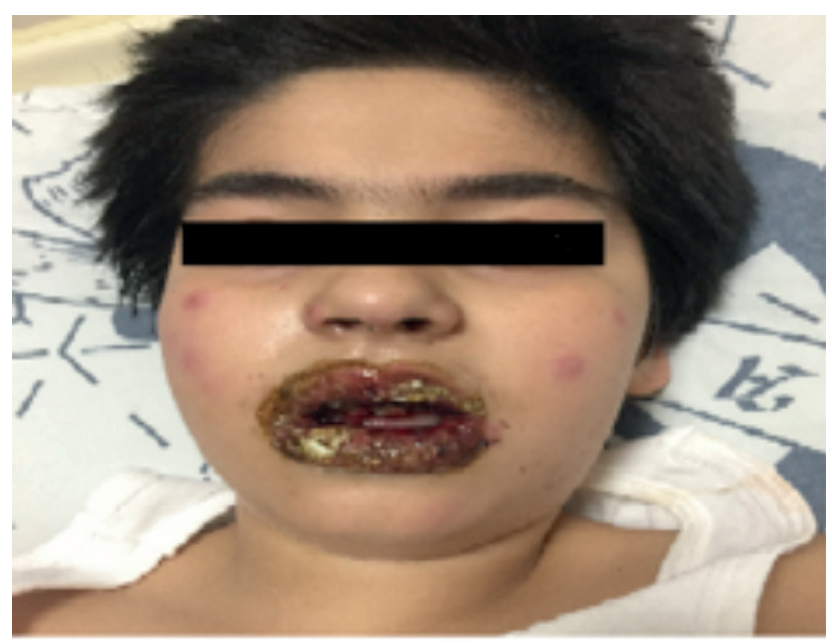

Figure 1. Widespread lesions on the mouth and on the lips, several rashes of maculopapules on the face and thrombocyte numbers were $6930 / \mathrm{mm}^{3}$ and $305.000 /$ $\mathrm{mm}^{3}$ respectively. Left shift in peripheral smear $174 \%$ polymorphonuclear leucocyte) was detected. Erythrocyte sedimentation rate was $55 \mathrm{~mm} / \mathrm{h}$, and CRP was $14.9 \mathrm{mg} /$ $\mathrm{dL}(\mathrm{N}: 0-0.5 \mathrm{mg} / \mathrm{dL})$. His liver and kidney functions as well as serum electrolytes were within optimal range. Also, the following results were detected: rubella immunoglobulin (lg) $\mathrm{M}(-)$, IgG $(+)$, toxoplasma, cytomegalovirus, herpesvirus, hepatitis A and B, Epstein-Barr virus IgM (-) and IgG (+); and Borrelia IgM was detected as positive by ELISA method. No active factor was isolated by multiplex polymerase chain reaction panel for respiratory pathway. Western Blot experiment to confirm the positivity of Borrelia burgdorferi verified the positivity on four bands. Cerebrospinal fluid (CSF), glucose, protein and microscopic analyses were normal, and antibody detection was negative. Throat, blood, urine and CSF cultures did not show any growth. Electrocardiography (ECG), echocardiography (Echo) and cranial magnetic resonance imaging examinations were all within normal range.

Detailed full body examination of the patient did not reveal any evidence of the presence of ticks or tick bites. Ceftriaxone treatment $(75 \mathrm{mg} / \mathrm{kg} /$ day) was started. On the second day, the patient's fever was brought down, and facial nerve sensory and motor functions were completely normal in the second week. Oral ulcerations and wounds around the mouth were healed. The treatment was completed and he was discharged in the third week; and during periodical examinations, no complications were observed in the patient.

\section{Discussion}

Lyme disease is transmitted to humans by the Spirochete species "Borrelia burgdorferi". The initial cause was isolated by Willy Burgdorfer in 1982 from the tick species Ixodes dammini, which is found on the North American deer (6). The prevalence of Borrelia burgdorferi in our country is unclear, but the incidence has been increasing. Most of the literature published are case studies that include reports of adults living in the countryside. In our country, seropositivity is $6-44 \%$ in the risk groups, whereas it is $2-6 \%$ in normal populations, and varies depending on the region (7).

Clinical manifestations are divided into two phases as early and late. The early stage is grouped as localized and disseminated. The skin lesions called eritema migrans, are swollen, sharp and restricted, pale in the middle and bright red on the outer edge. They are typical in the early localized stage, and are seen in 50-60\% of the cases. Nonspecific systemic symptoms such as fever, headache, lethargy and myalgia are also findings observed in this stage. On the other hand, early disseminated stage is seen in $20 \%$ of the cases. The clinical findings specific for this stage are plaque or nodule-like multiple skin lesions that are smaller than eritema migrans and farther than the location of the tick bite, carditis, aseptic meningitis, facial paralysis, peripheric neuropathy transverse myelitis may be monitored. Prevalence of the neurological symptoms is higher in children. Late stage is 
observed months later in untreated cases. In this stage, primarily CNS involvement together with findings such as arthritis in large joints and encephalitis are observed (2). Findings of fatique, fever, extensive mouth sores and dried skin lesions, the presence of multiple squamous papular rashes different from eritema migrans, and unilateral facial paralysis led us to think of early disseminated stage. However, the ECG and Echo were normal. Possible findings of myocarditis and cardiac involvement with atrioventricular blocks were not observed in our patient.

Facial paralysis is seen in $11 \%$ of the Lyme disease cases, and in 30-40\% of the cases facial paralysis is reported as bilateral (8). It can emerge within few days of, or three weeks after the disease onset, and the prognosis is generally good (9). A study conducted by Clark et al. (10) reported that $99.2 \%$ of the facial paralysis related to Lyme disease spontaneously recovers. A case report from our country too reported that a patient completely recovered at the end of the first month (11). Our patient also developed acute facial paralysis in the second week, and on the fourth day of the treatment full response was obtained and the facial paralysis was fully recovered.

For diagnosis, the antibody detection is conducted by ELISA or Immunofluorescence Antibody test. In the second step of diagnosis, confirmation with Western Blot is suggested (4). However, a study conducted in Canada reported that the positivity of nine out of 40 patients (22.5\%) was detected by one or more ELISA tests, while Western Blot test gave negative results (12).

Oral doxycycline or amoxicillin is used for treatment during the early stage. On the other hand, in the case of neuroborreliosis and serious heart involvement, parenteral ceftriaxone treatment for 14-21 days is necessary (2). A complete remission is obtained in $80 \%$ of the cases with antibiotic treatment when facial neuropathy is present. Although spontaneous recovery is possible for isolated cranial neuropathies, the prevention of neurological complications is targeted by treatment with antibiotics. Because of the irregular use of amoxicillin, and the lumbar puncture procedure in order to eliminate the possible CNS involvement upon neurological findings, as well as the difficulties in oral intake due to the extensive oral wounds, the patient was treated with the appropriate dose of parenteral ceftriaxone. No complications have emerged in the patient who fully responded to the treatment.

In conclusion, Lyme disease is a rare infectious agent seen and detected as an etiological cause in the cases with facial neuropathy. However, the diagnosis of Lyme disease in our patient, who is neither living in the countryside nor has contact with animals, might be an indicator of the spreading of the disease, and the increase in the agent tick species in our country. Therefore, differential diagnosis should be considered and serum antibodies should be investigated in such cases. Early diagnosis and treatment at the onset of the disease will help control the symptoms and prevent neurological complications.

\section{Ethics}

Informed Consent: Consent form was filled out by the family of the patient.

Peer-review: Externally peer-reviewed.

\section{Authorship Contributions}

Surgical and Medical Practices: E.Ö., D.G., Concept: E.Ö., D.G., Design: E.Ö., D.G., Data Collection or Processing: E.Ö., D.G., Analysis or Interpretation: E.Ö., D.G., Literature Search: E.Ö., D.G., Writing: E.Ö., D.G.

Conflict of Interest: No conflict of interest was declared by the authors.

Financial Disclosure: The authors declared that this study received no financial support.

\section{References}

1. Stanek G, Wormser GP, Gray J, Strle F. Lyme borreliosis. Lancet 2012;4:461-73.

2. Kliegman RM, Stanton BF, St. Geme J. Nelson Textbook of Pediatrics. 20th ed. Philadelphia, Elsevier Saunders, 2015:1483-7.

3. Polat E, Turhan V. First report of three culture confirmed human Lyme cases in Turkey. (In Turkish) Mikrobiyol Bul 2010;44:133-9.

4. Yemişen M, Mete B. Lyme disease. (In Turkish) Journal of Experimental and Clinical Medicine. Deneyselve Klinik Tıp Dergisi 2012;29:169-74.

5. Arias G, Nogués J, Mañós M, Amilibia E, Dicenta M. Bilateral facial nerve palsy: four case reports. ORL J Otorhinolaryngol Relat Spec 1998;60:227-9.

6. Thaisetthawatkul P, Logigian EL. Peripheral nervous system manifestations of lyme borreliosis. J Clin Neuromuscul Dis 2002;3:165-71.

7. Bulut C, Tufan ZK. An overlooked disease of tick bites: Lyme disease. (In Turkish) Mikrobiyol Bul 2009;43:487-92.

8. Hız F, Bozkurt D, Karagöl T, Çelik A, Çınar M. Bilateral Facial Paralysis Due To Lyme Neuropahty : A Case Report. (In Turkish) Inönü Üniversitesi Tıp Fakültesi Dergisi 2005;12:1335.

9. López-Alberola RF. Neuroborreliosis and the pediatric population: a review. Rev Neurol 2006;42(Suppl 3):91-6.

10. Clark JR, Carlson RD, Sasaki CT, Pachner AR, Steere AC. Facial paralysis in Lyme disease. Laryngoscope 1985;95:1341-5.

11. Bozkurt MK, Saydam L. Bilateral facial neuropathy due to Lyme disease. (In Turkish) Tıp Araştırmaları Dergisi 2011;9:185-7.

12. Artsob H. Western Blot as a confirmatory test for Lyme disease. Can J Infect Dis 1993;4:115-6. 